Moszyński M., Więckowska M. (2014). Evolution of ecological financial market from the perspective of institutional economics Copernican Journal of Finance \& Accounting, 3(1), 121-133. http:// dx.doi.org/10.12775/CJFA.2014.010

\author{
Michat Moszyński, Marcelina Więckowska* \\ Nicolaus Copernicus University
}

\title{
EVOLUTION OF ECOLOGICAL FINANCIAL MARKET FROM THE PERSPECTIVE OF INSTITUTIONAL ECONOMICS
}

Keywords: ecological financial market, institutional economics, formal institutions, informal institutions.

J E L Classification: B52, D02, E02.

Abstract: In the market economy the "actors" act according to rules of the game - the institutions - which impose certain restrictions on their behavior, making it more predictable for the other participants, reduce risk and uncertainty, and furthermore lowers transaction costs, etc. Institutions can be broadly divided into formal (coming from the state) and informal (derived from market participants and their interactions). Market participants are trying to creatively interpret the rules for their own use. The financial sector is regarded as being particularly creative in its approach to the formal rules due to its flexibility, speed and innovation. In this context it is interesting to consider a growing interest of the participants of the commercial financial market in the idea of environmental protection from the perspective of institutional economics. This constitutes the aim of the study, which main concern is to answer the following questions: How can the ecological behavior of the financial market players be attributed to the new institutions? What are the driving forces behind this phenomenon? What sanctions are imposed for breaking informal rules? How do the formal and informal institutions interact? Finally, how could the state influence and reinforce such behavior?

Date of submission: February 27, 2014; date of acceptance: March 23, 2014.

* Contact information: moszyn@umk.pl, The Department of Economics, marcw@ doktorant.umk.pl, The Department of Finance Management, Faculty of Economic Sciences and Management, Nicolaus Copernicus University, Gagarina 13a, 87-100 Toruń, Poland. 


\title{
EWOLUCJA EKOLOGICZNEGO RYNKU FINANSOWEGO Z PERSPEKTYWY EKONOMII INSTYTUCJONALNEJ
}

Słowa kluczowe: ekologiczny rynek finansowy, ekonomia instytucjonalna, instytucje formalne, instytucje nieformalne.

Klasyfikacja J E L: B52, D02, E02.

\begin{abstract}
Abstrakt: W gospodarce rynkowej aktorzy działają według reguł gry - instytucji, które nakładają na ich zachowania pewne ograniczenia, sprawiają, że staje się ono bardziej przewidywalne dla innych uczestników rynku, zmniejszają ryzyko i niepewność, redukują koszty transakcyjne itp. Instytucje można najogólniej podzielić na formalne (pochodzące od państwa i jego organów) i nieformalne (pochodzące od uczestników rynku i ich interakcji). Uczestnicy rynku starają się w twórczy sposób interpretować reguły, pragnąc wykorzystać je na swój uży tek. Sektor finansowy postrzegany jest jako szczególnie twórczo podchodzący do reguł formalnych z uwagi na jego elastyczność, szybkość działania i innowacyjność. W tym kontekście za interesujące należy uznać rozważenie rosnącego zainteresowania komercyjnych uczestników rynku finansowego ochroną środowiska z perspektywy ekonomii instytucjonalnej. Stanowi to cel badawczy opracowania, zmierzającego do odpowiedzi na następujące pytania badawcze: Na ile ekologiczne zachowanie $\mathrm{w}$ aspekcie ochrony środowiska może być interpretowane jako nowa instytucja? Jakie jest podłoże powstawania takich instytucji? Jakie sankcje grożą za nieprzestrzeganie nowych nieformalnych reguł ekologicznych? Jakie relacje zachodzą pomiędzy regułami formalnymi a nieformalnymi? Jak państwo mogłoby sterować i wzmacniać tego typu zachowania?
\end{abstract}

Translated by Michał Moszyński

\section{IIIITRODUCTION}

Throughout the financial market certain trends with a strong ecological dimension can be observed. Market participants increasingly take into account in their actions aspects of environmental protection, expose efforts made to reduce environmental costs in their strategies, offer new products, finance environmental investments and conduct environmental accounting. These phenomena are complex and cover the entire spectrum of activities and behaviours at the micro level (enterprise and industry) and the macro level as well. Figuratively speaking, one can specify it as an ecological plane, which progressively penetrates more and more the whole financial market.

There are many factors contributing to the expansion of "green" financial market. We consider the ideas of corporate social responsibility (CSR) and socially responsible investment (SRI) which permeate through successive activities areas and market segments. Although some attempts at designing and con- 
trolling these ideas on the part of the state can be perceived, these opinions come mainly "from below" and are shaped by actors themselves. The philosophies of CSR and SRI, by definition, it is to do something more than simply obeying the bureaucratic regulations. They accelerate positive changes in the financial market not only by stimulating "responsible" investment, but also by their influence on the entire functioning of the financial markets architecture.

Our study concentrates on institutional explanations of these trends. There are reasons for considering, that this perspective covers crucial cognitive problems of ecological financial market development. Building on the achievements of an institutional approach in economic science, we can look for answers to several questions related to current and future expansion of green financial market. First of all, it seemingly contradicts the logic of economic calculus of rational agents striving only for maximum profits. We consider why such concepts have their right to exist and how the players take voluntarily new environmental responsibilities, often exceeding the formal requirements imposed by law. If ecological behaviour could be interpreted as a new informal rule of the game, one can ask about the mechanism of their formation and sanctions for non-compliance. Another area of research is the relationship between formal and informal rules and an attempt at projecting the further development of the market assuming an active state policy that would shape and reinforce positive actions of players in the market. Even at this early stage the hypothesis can be proposed that the future evolution of the ecological financial market depends largely on the appropriate identification of new informal rules and their skilful incorporation into a system of formal institutions by the state.

\section{THE RESEARCH METHODOLOGY AND THE COURSE OF THE RESEARCH PROCESS}

The study is mostly of a theoretical character. The phenomenon of the evolution of green financial market is analysed from the perspective of institutional economics. In the theoretical part, based on literature studies, the definition and typology of the institutions are presented, along with and the mechanism of their formation as well. Then an attempt is undertaken to explain the environment-friendly behaviour of the financial market participants and the development of new products associated with the so-called green finance. The empirical part using descriptive analysis illustrates the theoretical results with practical examples and data from the financial markets. The study ends with conclusions. 


\section{FORMAL AND INFORMAL RULES AS A MEDIUM FOR ENVIRONMENTAL VALUE}

The social life becomes more and more complex. No one can understand the intricate nexus of interactions of actors in the anonymized society. That is why we need institutions, described by North $(1990,3)$ as "rules of the game ... or, more formally, are the humanly devised constraints that shape human interaction. As a consequence they structure incentives in human exchange, whether political, social, or economic. Institutional change shapes the way societies evolve through time and hence is the key to understanding historical change." The rules reduce the complexity of mutual relations and help to foresee one's behaviour. Such devices constitute prerequisite condition for carrying out transactions on the micro-level and for the functioning of the market system as a whole. The economists stress the crucial role of institutions (rules of the game) in reducing transaction costs and uncertainty and in building up trust. However, the great part of social and economic life remains untouched by formal rules, but continues to be under the impact of the broad defined informal institutions such as norms, attitudes, taboos, conventions, rules of conduct and customs. Many formal institutions like rules of law have their roots in informal arrangements which have formalized over time. In such cases the rule is rather that of being discovered or invented, but not deliberately created. Citing the $18^{\text {th }}$ Century Scottish philosopher A. Ferguson one could call it "the product of human action but not of human design". The distinction between formal and informal institutions, which is not always clear, is the most important division that has to be applied in further analysis. While formal rules are enforced by official entities, informal institutions are largely self-enforcing. Another useful categorisation proposed by Helmke and Levitzky (2004) is based on the relationships between formal and informal institutions. When both produce similar results in the effective way (if they really "matter"), then the informal institutions are called complementary.

In the vast amount of literature of the subject, some mechanisms concerning the emergence of rules can be traced. Hayek (1973) explained it with an evolutionary process of discovering the best solutions for coping with the complexity problems and fragmentation of knowledge in the society.

As Hodgson (2006) states, institutions both constrain and enable behaviour. The existence of rules implies constrains. However, such a constraint can open up possibilities: it may enable choices and actions that otherwise would not exist. This perspective allows an interpretation of institutional "winners" 
and "losers". Some actors may drive institutional change, contribute to set up new rules to win access to new market niches and gain market advantage. The institutions can be considered as distributional instruments loaded with power implications. As the result the reinforced regulations constitute new market segments, and increases demand for new products and affecting wealth allocation. Finally, the state and its agencies, always eagerly extending their power by legislation, actively respond to such developments. There is a "demand for regulation" which has to be satisfied.

Rules are made of ideas, but only codified ideas can be regarded as institutions. The process of the formalization of the sustainable investment rules is still in progress. Presumably the origins of the rules stem from ideas of sustainable development and growing environmental concerns in the public. The wide set of rules was later invented by financial market participants in cooperation with the non-government organizations. Their rapidly extending scope enables a prediction of proceeding formalization of this subject by the state in the future. Aware of that actors, could anticipate and quickly react to the new market conditions being better prepared and familiar with new regulations. As experience with the smoke-free legislation illustrates, the process of rule evolving becomes self-enforcing in a manner of well-known phenomenon of a self-fulfilling prophecy and a snow-ball effect.

The expansion of informal rules is depicted from various points of view (schema 1). For the purpose of this article, we assume that, responsible investments are investments in responsible businesses. ESG (Environment, Social, Governance) are areas that refer to both investments and businesses. ESG are the extents of sustainability reporting and provides information and measures, which are supplements to traditional financial criteria in selecting investment. CSR and SRI are concepts which penetrate contemporary finance and the ones among many determinants of development ecological financial market. The existence and practice of social (including environmental) concepts may constitute some kind of ESG filter for capital movement in investment process. 
Schema 1. The research area of the influence of formal and informal institutions on the ecological financial market development

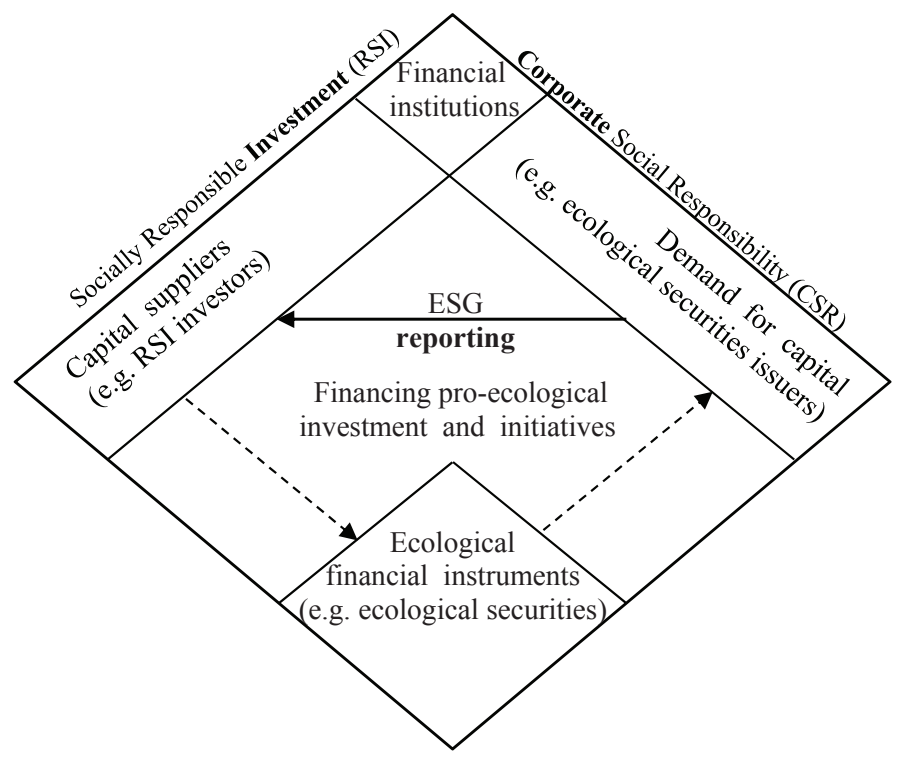

S o u r c e s : Authors' own elaborations.

\section{CSR IN THE CONTEXT OF ENVIRONMENTAL PROTECTION}

\section{- INTERACTION OF RULES}

Implementation the concept of corporate social responsibility may be an impetus to improve eco-efficiency, introduction of eco-innovations or building green image. However dissemination of the idea of CSR generates both opportunities and risk. The need to comply with environmental regulatory obligations is indisputable, while the formation and interaction of informal rules in this context is still an unexamined phenomenon. In an era of increasing ecological awareness and changing consumer preferences, the main track of interaction of informal rules occurs between corporations and society (including stakeholders). But not only - in this game the contest also takes place also between particular corporations (mostly in terms of building competitive advantage). 
Schema 2. Sanctions for non-compliance in the environmental protection area imposed on financial market participants

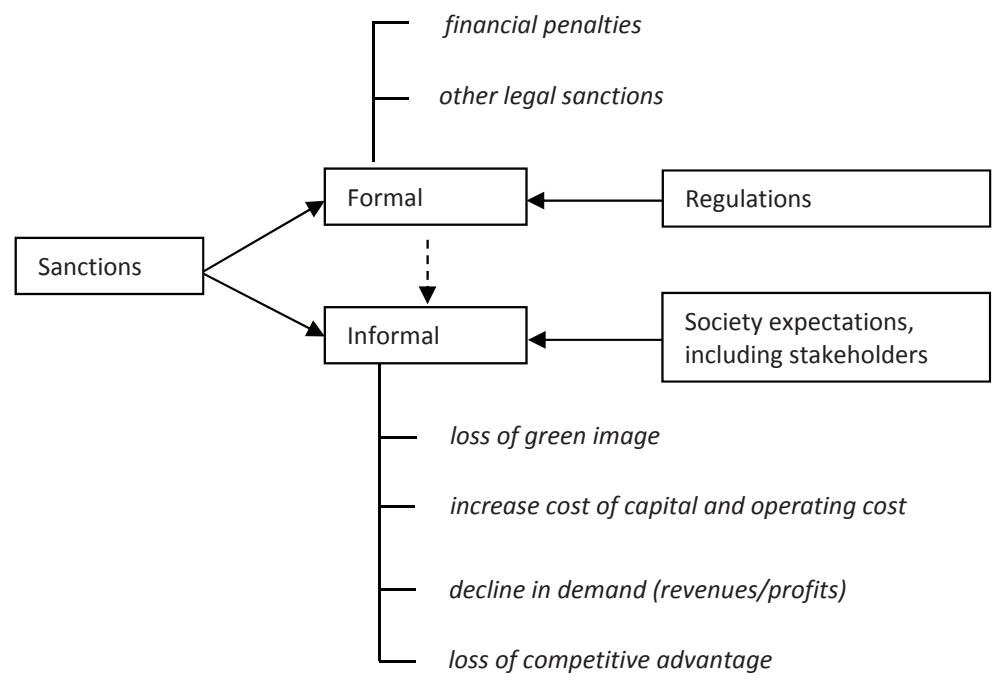

S o u r c e s : Authors' own elaborations.

The existence of rules entails inevitability to adapt them and bares a various range of sanctions for non-compliance (schema 2). Analogically to categorise the institutions mentioned above, they can be divided into formal and informal. The first group consists of penalties imposed by the state or its agencies on the basis of the law. The much more fascinating set of restrictions make up informal sanctions coming from the mechanism of obligation, or simply because following the rules is in the best interests of individuals who may find themselves in a "Nash equilibrium" where everyone is better off by from following the trend. The pressure from the outside is put by stakeholders and imposed spontaneously by market forces. Their impact, however, can be tremendous and preventive. The most extreme examples of environmental sanction relate to the result of ecological disaster. A clear illustration of this happened in the Gulf of Mexico in 2010, following the explosion of oil rig (owned by BP) ${ }^{1}$.

1 The disaster caused decline in stock prices by half. Furthermore the BP set up 20 billion USD fund to pay all legitimate claims for compensation. Part of the expenses concerned attempts to restore the environment. Oil spill result in more stringent regulation of oil and gas activities in the US and elsewhere, particularly relating to environmental (BP Annual Report, 2010). 
Furthermore, many ecological offences are recognized and publicized by the ecological lobby. PGE group and the cases of power stations in Opole in 2012 and Bełchatów in 2013 are the best examples. An interesting tactic of ecologist is to try and to influence the investors decision making (case of initial public offering ZE PAK) ${ }^{2}$. But for now, shareholder activism in Polish capital market in the field of environmental protection is practically invisible. It does not mean it would change in the future as the investors' awareness will spread.

How does CSR look like in the practice of financial institutions? The financial sector (analogous to security issuers in other sectors) is not free from assessment. An international trend indicates, that the reduction of paper usage and occasional philanthropic gestures may be insufficient. As the reporting of CSR policy gradually becomes wider industry practice (see subsection 4), transparency regarding the environmental responsibility is still selective (mostly information concerning carbon footprints or energy self-sufficiency); whereas essential in banking, activities should be verifications of environmental standards in financing undertakings. Society and stakeholders want to know, if funded business do not damage the environment. Pressure groups are finally beginning to reveal some information in this aspect. Report Dirty Profits (Facing finance, 2011), for instance, disclosures financial institutions which support business activities harming the environment. There is additional evidence, that in the future to build reputations, the financial sector disclosure will be even deeper, more accurate and more comprehensive and the assessment of environmental risk will become more important.

\section{TOWARDS THE FORMALIZATION OF SUSTAINABLE INVESTMENT RULES}

The socially responsible investment (SRI) is "the other side of the coin" in the process of ecological capital flow. The roots of the SRI concept are searched even in ancient time in religious teachings and injunction. Religious values (especially in Islam - for Shariah-compliant rules, but also in Christianity and Judaism) require using money in ethical way and prohibiting making an investment in specific fields (Urban, 2011). Sustainable investment market in its current form was born in the United States and then in Europe in 1920s. (Tsukushi, 2003). Initially implementation of the RSI ideas took place mostly by applying

2 Ecologists has informed investors and analysts that the ZE PAK prospectus does not take into account all risk factors, which the company charges (Parkiet, 20.12.2012). 
negative screening criteria in investment decision. Nowadays negative screens may refer to controversial regimes such as Sudan and Iran, certain activities such as production of weapon or selected companies that for example harm the environment. Ecological investments also should be connected with investments in green industries or ecological leaders from other sectors (Dziawgo, 1997; GSIA, 2013). Table 1 contains empirical evidence of presence and importance of the SRI idea.

Table 1. Size and structure the global SRI assets by region in 2012

\begin{tabular}{|l|c|c|}
\hline \hline \multicolumn{1}{|c|}{ Region } & $\begin{array}{c}\text { Size the global SRI assets } \\
\text { (in billion USD) }\end{array}$ & $\begin{array}{c}\text { Structure the global SRI asset } \\
\text { (in \%) }\end{array}$ \\
\hline \hline Europe & 8758 & 64.5 \\
\hline United States & 3740 & 27.6 \\
\hline Canada & 589 & 4.3 \\
\hline Africa & 229 & 1.7 \\
\hline Australia/NZ & 178 & 1.3 \\
\hline Asia (excl.-Japan) & 64 & 0.5 \\
\hline Japan & 10 & 0.1 \\
\hline Total & 13568 & 100.0 \\
\hline \hline
\end{tabular}

S o u r c e s: GSIA 2013.

The interest in the subject of responsible investment is extraordinary and constantly gaining in importance. Institutional investors create individual SRI policy on their own or implement rules developed by international initiatives such as Principles for Responsible Investment (PRI, supported by the United Nations). Since 2006 the PRI rules have been implemented by 1245 signatories (currently representing assets worth 34 trillion USD). Another interesting example is the UNEP FI (United Nations Environment Programme Finance Initiative) that offer the best practice in the field of integration of environmental and social considerations into all aspects of operations (including investment and trading activities). Moreover, investors bring together and create groups to represent their interests in the process of investing in climate change solutions. 
This kind of organizations were formed almost in every parts of the world (for example INCR, IIGCC, IGCC, AIGCC) ${ }^{3}$.

And finally, the highest degree of formalization regarding ecological and ethical investments concerns the legally sanctioned principles. In some countries (e.g. Norway, Sweden, New Zealand) the institutional investors such as sovereign wealth funds and pension funds are obliged by law to consider ESG factors in their decision making. In turn, the European Commission is considering introducing a set of that would obligate investment funds and financial institutions to inform their clients about "any ethical or responsible investment criteria they apply or any standards and codes to which they adhere" (COM, 2011).

\section{ESG REPORTING - FROM VOLUNTARY PRACTICE TO NECESSARY OBLIGATIONS}

It is required to have a smooth conduit for information between sustainable business, and sustainable investment financing activities. Transparency regarding the business activity and an increasing need for disclosure, also the non-financial factor to comprehensively assess the investment risk and compatibility with declared investment policy. In other words, in order to enable capital supplier to screening for ESG rules, the reporting within these areas is needed ${ }^{4}$. Sustainability reporting is another global trend initially taking form of good practice and gradually sticking into regulatory framework.

According to KPMG (2013) survey, 71\% of the 4100 largest companies across each surveyed countries ${ }^{5}$ published a sustainability report, compared with 64\% of companies researched in 2011 (and 28\% in 2002). Whereas among the world's largest 250 companies, the proportion is 93\% (finance sector, insurance and securities market entities representing $25 \%$ of the sample). Authors of the reports emphasize that the recent increase in reporting has been driven by regulatory requirements in such countries as: France, Denmark and South Africa. In Japan for example, there exist the guidelines to report on environmental impact (including GHG emissions). Moreover, companies listed on

${ }^{3}$ INCR - Investor Network on Climate Risk (USA), IIGCC - Institutional Investors Group on Climate Change (Europe), IGCC - Investor Group on Climate Change (Australia and New Zealand), AIGCC - Asian Investor Group on Climate Change (Asia).

${ }^{4}$ Another way to identify and assess the level of investment sustainability are: ecoratings, sustainable stock market indices or various form of ecological certifications.

5 The survey sample covers 100 largest companies in 41 countries (4100 companies in total), the last survey in 2011 covered 34 countries (34000 companies). 
the stock exchange (e.g. India, Singapore, Malaysia) also had to adopt sustainability reporting to meet the requirements imposed by the stock exchange. The London Stock Exchange, for instance, since 2013 has required reporting on GHG emission. An interesting case is Central Bank of Nigeria, which stipulates financial service companies to report on corporate responsibility.

It is worth mentioning that $78 \%$ of reporting companies worldwide refer to the Global Reporting Initiative ${ }^{6}$ (GRI) guidelines. GRI offers sustainability reporting standard, which (as we can see) establishes global practice among the largest companies. The standards emphasize the disclosure of real and measurable indicators in environmental reporting. Current state of corporate responsibility reporting clearly indicates that voluntary practice is incrementally transforming into necessary obligations.

Poland is indicated (KPMG, 2013) as country with lower than average sustainability reporting rates at the level of $56 \%$. The survey conducted by SEG (2013) in details exposes universality on quality of ESG reporting among listed companies on the Warsaw Stock Exchange and NewConnect. From 866 companies, 711 (82,2\% of total) do not publish environmental information or their reporting includes information of minor importance. However, it is worth mentioning that there are four commercial banks among the leaders in ESG reporting (top 10), which are: BGŻ, City Handlowy, Millennium, BPH. Examples of green actions and ecological financial product offer by the leaders include: Clean Energy Bank Loan, $\mathrm{WWF}^{7}$ credit card, green investment funds, planting trees (in place of resignation from paper bank statement by clients), eco-educational meeting, etc.

To sum up, it must be noted, that to be able to disclose environmental information, Polish firms should take on an increased amount of green initiatives. Besides, environmental reporting is not only way to exaggerate ecological image, but also may be comprehensive assessment tools in investment decision process. However the scope and level impact of social and environmental factors in the securities price is still subject of research. It should be noted that the

${ }^{6}$ GRI was founded in 1997. In 1998 a multi-stakeholder Steering Committee established GRI's guidance - based on CERES Principles for responsible environmental conduct, but Committee incorporated also new area: social, economic, and governance issues (see more: https://www.globalreporting.org).

7 WWF - World Wide Fund for Nature (ecological organization), see more about credit card: http://www.wwf.pl/mozesz_pomoc/karta_kredytowa/ and Dziawgo, 2010, p. 147. 
tardiness of Polish companies may hinder them complying with prospective European Union regulations.

\section{THE OUTCOME OF THE RESEARCH PROCESS AND CONCLUSIONS}

The evolution of the green financial market seen through the lens of institutional approach allows us to gain a comprehensive insight into causes, current course of business processes and their consequences. The conceptions of CSR and SRI fall on fertile ground, driven by forces from below assuming the shape of informal rules created by market leaders. These rules rely on enforcement mechanisms (sanctions) which occur in various forms. Their powerful effects prove how strong the public awareness and expectations of market participants are.

The predomination of informal institutions over formal ones will probably remain. It is not possible to regulate every aspect of activity, moreover it is not reasonable to do so. However, beyond the examples of voluntary codified rules in the nature of good practice, belonging to various organizations and initiatives, recognizing the theme by the stock exchange, some clear signals from the state and international organizations willing to formalize these areas are visible. There is much evidence to draw the conclusion of the future trends towards formalization and growing legislation activities in the areas of CSR and SRI. The sane and realistic regulation policy can be desirable and successful, if the complementary relation between formal and informal institutions will be preserved.

\section{1- REFERENCES}

BP Annual Report (2010), http://www.bp.com/content/dam/bp/pdf/investors/BP_ Annual_Report_and_Form_20F.pdf.

COM (2011) 681 final, Communication from the Commission to the European Parliament, the Council, the European Economic and Social Committee and the Committee of the Regions. A renewed EU strategy 2011-14 for Corporate Social Responsibility, Brussels, http://eur-lex.europa.eu/LexUriServ/LexUriServ.do?uri=CELEX:52011DC0681:EN:NOT (accessed: 20.02.2014).

Dziawgo L. (1997), Papiery wartościowe w ochronie środowiska, Dom Organizatora, Toruń.

Dziawgo L. (2010), Zielony rynek finansowy. Ekologiczna ewolucja rynku finansowego, PWE, Warszawa.

Facing finance (2011), Dirty Profits, http://www.facing-finance.org/wp-content/ blogs.dir/16/files/2012/12/ff_dirtyprofits.pdf (accessed: 20.02.2014). 
GSIA - Global Sustainable Investment Alliance (2013), Global sustainable investment review 2012, January, http://www.gsi-alliance.org/resources (accessed: 19.02.2014).

Hayek F.A. (1973), Law, Legislation and Liberty, Vol. 1 Rules and Order, Routledge, London. http://dx.doi.org/10.7208/chicago/9780226321233.001.0001.

Helmke G., Levitzky S. (2004). Informal Institutions and Comparative Politics: A Research Agenda. Perspectives on Politics, vol. 2, no. 4. http://dx.doi.org/10.1017/ S1537592704040472.

Hodgson G.M. (2006). What Are Institutions? Journal of Economic Issues, vol. XL, no. 1, March.

KMPG (2013), The KPMG Survey of Corporate Responsibility Reporting 2013, KPMG International.

North D.C. (1990), Institutions, Institutional Change and Economic Performance, Cambridge, Cambridge University Press. http://dx.doi.org/10.1017/CB09780511 808678.003.

Parkiet Gazeta Giełdy (20.12.2012), Ekolodzy i potencjalny błąd w prospekcie, http:// www.parkiet.com/artykul/1287227-Ekolodzy-i-potencjalny-blad-w-prospekcie. html (accessed: 22.02.2014).

SEG - Stowarzyszenie Emitentów Giełdowych (2013), Transparentność w obszarze ESG jako element przewagi konkurencyjnej spółki giełdowej, R. Sroka (ed.), Warszawa.

Tsukushi M. (2003), History of SRI and eco-funds in Japan, [in:] Finance and Natural Environment. Experience of Poland against the background of developed market economies, L. Dziawgo, D. Dziawgo (ed.), Toruń.

Urban D. (2011), Zarys koncepcji inwestowania społecznie odpowiedzialnego, Acta Univesitatis Lodziensis, Folia Oeconomica 261.

Websites: BGŹ, http://www.bgz.pl/downloads/o_banku/BGZ_CSR_raport_elektroniczny_final.pdf (accessed: 20.02.2014).

Websites: City Handlowy, http://www.citibank.pl/poland/kronenberg/polish/6606. htm (accessed: 12.02.2014).

Websites: Global Reporting Initiative (GRI), https://www.globalreporting.org (accessed: 11.02.2014).

Websites: Millennium, http://www.bankmillennium.pl/pl/o-banku/csr/dzialania/ srodowisko (accessed: 20.02.2014).

Websites: Principles for Responsible Investment (PRI), http://www.unpri.org (accessed: 10.02.2014).

Websites: United Nations Environment Programme Finance Initiative (UNEP FI), http://www.unepfi.org (accessed: 11.02.2014).

Websites: World Wide Fund for Nature (WWF), http://www.wwf.pl/mozesz_pomoc/ karta_kredytowa (accessed: 12.02.2014). 
